deaths occurred immediately after admission, the fourth was from a non-infective cause, and the fifth followed prolonged non-specific gastroenteritis. So it is suggested that antibiotics are of real value in treating associated infection but play little part in the severe case or in the control or spread of infection.

Even in the developed countries gastroenteritis is still one of the commonest diseases of infancy, with a hospital mortality rate of over $1 \%$. It is therefore remarkable that the aetiology is unknown in most cases, that the chemical pathology of the disease is still imperfectly understood, and that there is little agreement on the optimum treatment.

We wish to thank Dr. S. I. Jacobs and Dr. D. I. K. Evans for providing the laboratory results and Mr. A. S. Gibbs and Mrs. A. Fish for the statistical analyses.

\section{REFERENCES}

Anderson, E. S. (1968). British Medical fournal, 1, 293.

Barness, L. A., and Young, L. N. (1964). Pediatric Clinics of North Barness, L. A., and

America, 11. 1091.
British Medical fournal, 1968, 1, 70.

Cornfeld, D. (1964). Pediatric Clinics of North America, 11, 963.

Cushing, A. H. (1967). Pediatrics, 40, 656.

Ejercito, P. M., Hidea, H. N., and Pesignan, T. P. (1966). Fournal of the Philippine Medical Association, 42, 747.

Finberg, L., and Harrison, H. E. (1955). Pediatrics, 16, 1

General Register Office (1969). Registrar General's Statistical Review of England and $W$ ales for the year 1967. London, H.M.S.O.
Harrison, H. E., and Finberg, L. (1964). Pediatric Clinics of North America, 11, 955.

Hirschhorn, N., Lindenbaum, J., Greenough, W. B., and Alam, S. M. (1966). Lancet, 2, 128.

Hughes, M. H., Greaves, J. L., and Bettelheim, K. A. (1968). fournal of Clinical Pathology, 21, 387.

Lamb, R. (1968). Scottish Medical fournal, 13, 9.

Lie Kian Joe, et al. (1966). Bulletin of the World Health Organization, 34, 197

Macaulav, D., and Blackhall, M. I. (1961). Archives of Diseases in

Childhood, 36, 543.
Medical Research Council (1952). Memorandum, No. 26.

Moffet, H. L., Shulenberger, H. K., and Burkholder, E. R. (1968) fournal of Pediatrics, 72,

Moore, H. A., de la Cruz. E., and Vargas-Mendez, O. (1966). American fournal of Public Health, 56, 276.

Moorhouse, E. C., and McKay, L. (1968). British Medical fournal, 2, 741 .

Morris-Jones, P. H., Houston, I. B., and Evans, R. C. (1967). Lancet, 2, 1385

Ramsay, A. M. (1968). British Medical fournal, 2, 347.

Ramsay, A. M., and Emond, R. T. D. (1967). Infectious Diseases, p. 169. London, Heinemann

Smith, H. W., and Halls, S. (1967). Fournal of Pathology and Bacteriology, 93, 499.

Smith, J. (1955). The Aetiology of Epidemic Infantile Gastro-Enteritis. Edinburgh, Royal College of Physicians.

Taylor, W. H. (1968). Public Health (London), 82, 230.

Taylor, J., Wilkins, M. P., and Payne, J. M. (196i). British fournal of Experimental Pathology, 42, 43.

Teree, T. M., Mirabel-Font, E., Ortiz, A., and Wallace, W. M. (1965). Pediatrics, 36, 704.

Valman, H. B., and Wilmers, M. J. (1969). Lancet, 1, 1122

Warin. J. F. (1968). British Medical fournal, 1. 248.

Wheatley, D. (1968). Archives of Diseases in Childhood, 43, 53.

Wilson, G. S., and Miles, A. A. (1964). Topley and Wilson's Principles of Bacteriology and Immunity, 5th ed., vol. 2, p. 1897 . London, Arnold.

\title{
Rifampicin-induced Immune Thrombocytopenia
}

\author{
M. A. BLAJCHMAN,* M.D.; R. C. LOWRY, $\dagger$ M.B., M.R.C.P. ; J. E. PETTIT, $\ddagger$ M.B., сH.B. \\ PETER STRADLING, $\$ M.D., F.R.C.P.
}

\begin{abstract}
Summary: A case is reported in which severe thrombocytopenia occurred during administration and readministration of rifampicin. The patient's erythrocytes gave a positive direct antiglobulin test due to complement on the red cell surface; in the serum, complement-fixing antibodies were detected which were directed against the drug.

Immunological studies showed antibodies, of both IgG and IgM type, capable of fixing complement to both normal and the patient's platelets, but only in the presence of rifampicin. In addition the IgM type of antibody (but not the IgG) was capable of fixing complement to normal red cells; again only in the presence of the drug.
\end{abstract}

\section{Introduction}

Rifampicin is a most useful and effective oral antituberculosis agent of great therapeutic promise. It has hitherto been considered of remarkably low toxicity and, together with ethambutol, is probably the combination of choice in the treatment of tuberculosis resistant to the primary drugs (Canetti et al., 1968; Verbist and Gyselen, 1968; Pines et al., 1970).

In the present report we describe the case of a patient who developed thrombocytopenia while receiving ethambutol plus rifampicin, and in whom readministration of rifampicin resulted in an acute, severe thrombocytopenia. Thrombocytopenia is a well-known complication following the administ-

*Honorary Registrar, Department of Haematology.

tRegistrar and Tutor in Respiratory Diseases.

$\neq$ Registrar, Department of Haematology.

Chest Physician and Senior Lecturer in Respiratory Diseases.

Royal Postgraduate Medical School, Hammersmith Hospital, London W.12. ration of many different drugs and chemicals (Horowitz and Nachman, 1965), and is characterized by a rapid lowering of the platelet count whenever the offending drug is taken by the sensitized individual. The aetiological relationship between the thrombocytopenia and the drug in such instances is often difficult to confirm. In the present case, however, antibodies in the patient's serum were detected which could fix complement to normal red cells and platelets only in the presence of the offending drug. It is believed, therefore, that this patient had an immune thrombocytopenia due to antibodies directed against rifampicin. To our knowledge this represents the first report of thrombocytopenia due to rifampicin, despite its use in tens of thousands of patients since 1967.

\section{Clinical Findings}

The patient, a 56-year-old West Indian woman, came to this country in 1964. Essential hypertension was diagnosed in 1965 and has been treated continuously since then with methyldopa and frusemide. The following year she developed tuberculous peritonitis.with ascites and an associated pleural effusion; acid-fast bacilli were isolated from both pleural and ascitic fluids. She received 18 months' therapy with streptomycin, sodium paraaminosalicylate (P.A.S.), and isoniazid. In 1968 a diagnosis of maturity-onset diabetes was made and managed with appropriate dieting only.

In December 1968 she had a sudden onset of left hemiparesis and left homonomous hemianopia with focal fits leading to grand mal seizures. Acid-fast bacilli were found on direct examination of her sputum on one occasion, but cultures for Mycobacterium tuberculosis were negative. A diagnosis of tuberculous meningitis was made, and over the following seven months she received, owing to toxicity and hypersensitivities, various combinations of streptomycin, pyrazinamide, ethionamide, ethambutol, and 
isoniazid. From July 1969 the regimen was streptomycin $1 \mathrm{~g}$., plus ethambutol 1,200 mg., plus rifampicin 1,200 mg. twice weekly, the streptomycin being discontinued owing to ototoxicity in October 1969. In January 1970, after seven months continuous twiceweekly therapy with ethambutol and rifampicin, she complained of nose-bleeding, spots on the tongue, and throbbing headaches two hours after taking the tablets.

Physical Examination.-The tongue and buccal mucous membrane showed purpuric eruptions, $0.5 \mathrm{~cm}$. in diameter, which faded 12 hours after administration of ethambutol and rifampicin. There was no hepatosplenomegaly. The blood pressure was $160 / 110$. There were no other relevant physical findings.

Haematological Investigations.-The haemoglobin was 14.2 g. $/ 100 \mathrm{ml}$., P.C.V. $16 \%$, platelets $75,000 / \mathrm{cu}$. mm., and total white cell count $5,000 / \mathrm{cu}$. mm. (neutrophils $55 \%$, eosinophils $4 \%$, lymphocytes $32 \%$, monocytes $9 \%$ ). The red cell morphology was normal.

Subsequent Course (see Chart).-The patient was admitted to hospital for trial doses of ethambutol and rifampicin. Six days after admission she received $600 \mathrm{mg}$. of ethambutol without any change in platelet count. The following day $600 \mathrm{mg}$. of rifampicin

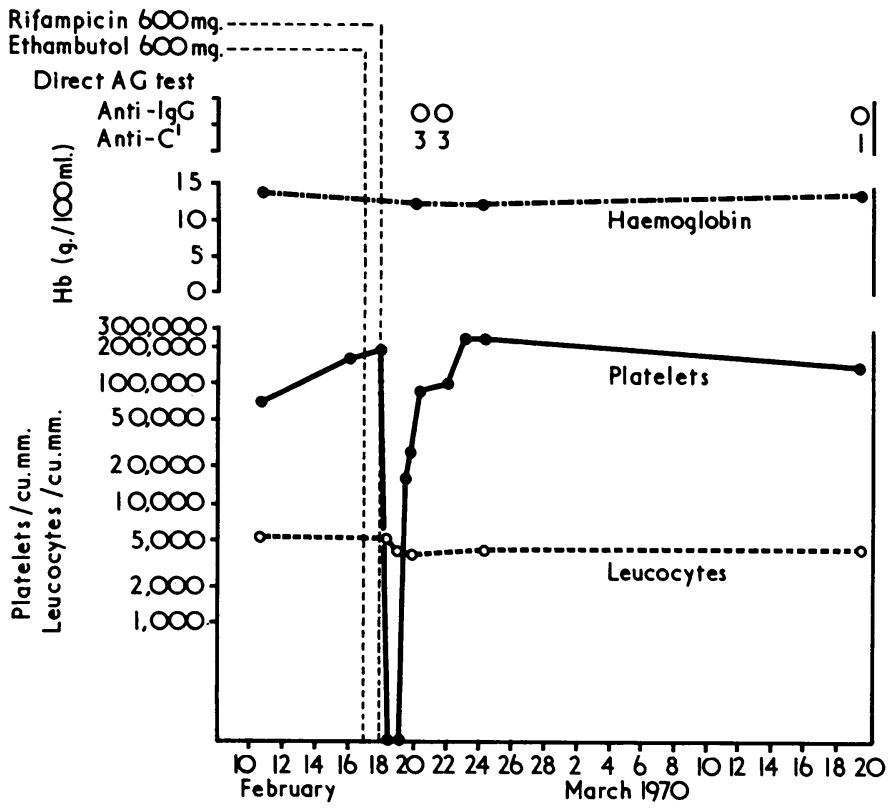

Haematological findings during the provocative tests with ethambutol and rifampicin.

was administered, and three hours later the platelet count had dropped from 180,000 to $2,000 / \mathrm{cu}$. mm. Subsequent platelet counts, at $7 \frac{1}{2}$ and 10 hours after administration of the drug showed a profound thrombocytopenia with no platelets demonstrable. She immediately complained of headache, and epistaxis began 10 hours after the rifampicin had been given. At this time haemorrhagic eruptions appeared on the tongue and the buccal aspect of her lower lip. The next day the platelet count began to rise, the epistaxis had stopped, and the headache was no longer present. The platelet count continued to rise and five days after administration of rifampicin was $259,000 / \mathrm{cu}$. $\mathrm{mm}$. The drug appeared to produce no overt haemolysis : the maximum reticulocyte count noted was $2.8 \%$. One month after her last dose of rifampicin she was well with a platelet count of $130,000 / \mathrm{cu} . \mathrm{mm}$.

\section{Methods}

\section{Serology}

Direct Antiglobulin Tests.-These were carried out on the patient's red blood cells by standard techniques with a broadspectrum antiglobulin serum, an anti-IgG serum, an anti-IgA serum, an anti-IgM serum, and an anticomplement serum (Dacie and Lewis, 1968).
Indirect Red Cell Antiglobulin Test Using Rifampicin.-This test was carried out as described by Harris (1956) using rifampicin in a final concentration of $4.68 \mathrm{mg} . / 100 \mathrm{ml}$., which had been determined as the optimal concentration in preliminary studies. An anti-"non-gamma" antiserum was used in its optimal dilution of 1 to 4. In preliminary studies it had been found that immunoglobulins were not detectable on the normal red cells sensitized in the test.

Platelet Complement Fixation Test.-The method used was that described by Aster et al. (1964). For the various tests we used equal volumes of the patient's serum (or serum fraction), normal and patient platelet suspensions, rifampicin solution $(37.5 \mathrm{mg} . / 100 \mathrm{ml}$.$) , and guinea-pig complement. Controls were$ simultaneously carried out with normal AB serum, the patient's serum in the absence of the drug, the drug solution alone, and the patient's (or control) serum in the presence of the drug but in the absence of platelet suspension.

Clot Retraction Inhibition.-One-millilitre volumes of varying dilutions of rifampicin in saline were mixed with equal volumes of freshly drawn whole blood from the patient and allowed to clot in glass tubes at $37^{\circ} \mathrm{C}$. The clots were inspected for defective clot retraction at one hour and 24 hours. The experiment was controlled by observing clot retraction, saline in place of the rifampicin solution being used with the patient's blood. Because it was possible that it may have been a metabolite of the drug which was responsible for platelet destruction, varying dilutions of the patient's urine, collected in the 24-hour period after rifampicin administration, were also tested for inhibition of clot retraction.

\section{Characterization of the Antibody}

Serum Fractionation.-Stepwise elution from DEAE-cellulose was used as described by Tomasi and Kunkel (1964). The immunoglobulin content of the four fractions thus obtained included only IgG in fraction 1; small quantities of IgG and IgA in fraction 2; mainly IgA, with a small quantity of IgG, in fraction 3; and only IgM in fraction 4

Treatment of the Immunoglobulins with 2-Mercaptoethanol (Dacie and Lewis, 1968).-The patient's serum, normal serum, and the various immunoglobulin fractions were treated with 2 mercaptoethanol and tested, along with appropriate controls, by the platelet complement fixation test and the indirect antiglobulin test.

\section{Results}

Direct Antiglobulin Test.-The day after rifampicin administration the direct antiglobulin test gave a moderately strong $(3+)$ reaction, the red cells being agglutinated by the broad spectrum and by the anticomplement serum only. One month later the direct antiglobulin test was weakly positive $(1+)$, again due to complement only on the red cell surface. This positive test is unlikely to be due to methyldopa. In patients under treatment with this drug the red cells are agglutinated only by the anti-IgG antiserum.

Indirect Antiglobulin Test Using Rifampicin.-The results are shown in Table I. The patient's serum sensitized normal red cells

TABLE I.-Indirect Antiglobulin Tests in the Presence of Rifampicin

\begin{tabular}{c|c|c|c|c|c|c|c}
\hline Tests & $\begin{array}{c}\text { Patient's } \\
\text { Serum }\end{array}$ & $\begin{array}{c}\text { Normal } \\
\text { Serum }\end{array}$ & $\begin{array}{c}\text { Normal } \\
\text { Erythrocytes }\end{array}$ & $\begin{array}{c}\text { Comple- } \\
\text { ment }\end{array}$ & Saline & Rifampicin & Results \\
\hline $\mathbf{1}$ & $\times$ & $\times$ & $\times$ & $\times$ & & $\times$ & $\mathbf{2 +}$ \\
$\mathbf{2}$ & $\times$ & $\times$ & $\times$ & $\times$ & $\times$ & $\times$ & - \\
$\mathbf{3}$ & $\times$ & & $\times$ & $\times$ & $\times$ & $\times$ & - \\
$\mathbf{5}$ & $\times$ & & $\times$ & $\times$ & $\times$ & $\times$ & - \\
\hline
\end{tabular}

$x$ indicates the constituents used in the individual tests.

to agglutination by the anti-"non-gamma" antiserum only in the presence of both drug and complement : treated with 2-mercaptoethanol it gave negative results. The patient's red blood cells could not be used as they were already coated with complement. Of the four serum fractions made, only that fraction containing 
TABle II.-Results of Platelet Complement Fixation Tests

\begin{tabular}{|c|c|c|c|c|c|c|c|c|c|c|c|c|c|c|c|}
\hline & & & & & & & & & \multirow{2}{*}{$\begin{array}{l}\text { 2-Mercaptoethanol } \\
\text { Treated }\end{array}$} & \multicolumn{2}{|c|}{ Normal Platelets } & \multicolumn{2}{|c|}{ Patient's Platelets } & \multicolumn{2}{|c|}{ No Platelets } \\
\hline & & & & & & & & & & + Drug & + Saline & + Drug & + Saline & + Drug & + Saline \\
\hline Patient's serum & . & . & . & . & . & .. & $\ldots$ & $\cdots\{$ & $\begin{array}{l}\text { No } \\
\text { Yes }\end{array}$ & + & $\overline{-}$ & + & $\underline{-}$ & $=$ & $\overline{-}$ \\
\hline Normal serum & . & . & . & . & .. & .. & .. & $\cdots\{$ & $\begin{array}{l}\text { No } \\
\text { Yes }\end{array}$ & $\begin{array}{l}\cdots \\
-\end{array}$ & $\overline{-}$ & $\begin{array}{l}- \\
-\end{array}$ & $\overline{-}$ & $\overline{-}$ & $\ldots$ \\
\hline IgG fraction & . & . & .. & . & . & . & . & $\cdots\{$ & $\begin{array}{l}\text { No } \\
\text { Yes }\end{array}$ & $\begin{array}{l}+ \\
+\end{array}$ & - & + & $\underline{-}$ & - & - \\
\hline IgA fraction & . & $\cdots$ & .. & . & . & . & .. & $\cdots\{$ & $\begin{array}{l}\text { No } \\
\text { Yes }\end{array}$ & $\overline{-}$ & $\overline{-}$ & $\overline{-}$ & $\overline{-}$ & - & $\cdots$ \\
\hline IgM fraction & . & . & . & . & . & . & .. & $\cdots\{$ & $\begin{array}{l}\text { No } \\
\text { Yes }\end{array}$ & \pm & - & \pm & $\underline{-}$ & - & - \\
\hline
\end{tabular}

IgM could sensitize normal red blood cells, in the presence of rifampicin and complement, to agglutinate in the antiglobulin reaction. This activity was found to be negative on reduction of that fraction with 2-mercaptoethanol. Titration of the patient's serum for anti-drug antibodies one day after administration of the drug gave a titre of 128; when tested one month later it was positive to a titre of 4.

Platelet Complement Fixation Test.-This test (Table II), in which both the patient's own platelets and normal platelets were used, showed complement fixation, only in the presence of the drug, to a titre of 4 . When whole serum was treated with 2-mercaptoethanol the complement fixing activity persisted. With the four fractions of the patient's serum, activity was found in both the IgG and IgM fractions; the latter fraction when treated with 2-mercaptoethanol lost all of its activity, confirming that the activity was due to IgM antibody. In serum from the patient tested one month after administration of rifampicin no platelet complement fixing was found.

Inhibition of Clot Retraction.-Clot retraction inhibition was not observed with the various drug or urine solutions.

\section{Discussion}

From the patient's clinical history, from the immunological studies, and from the platelet response to the readministration of the rifampicin this drug has probably produced platelet damage by some immunological mechanism. Two theories have been proposed as possible mechanisms for immune drug purpura. According to the Miescher-Schulman theory (Miescher and Miescher, 1952; Schulman, 1964), the drug binds to a plasma macromolecule and stimulates the production of antibody. The antibody then acts with the drug to form a soluble complex. This complex is then nonspecifically adsorbed to the platelet membrane and there fixes complement, which results in platelet damage. The Ackroyd theory (1962) postulates that the drug binds loosely to the platelet-membrane protein. This drug-platelet complex then acts as a haptene and stimulates antibody production. Finally, the antibody acts on the drug-platelet complex, so causing platelet damage.

Our studies indicate that the anti-rifampicin antibodies can be of both the IgM and the IgG classes of immunoglobulin. Why the patient developed acute thrombocytopenia without evidence of haemolytic anaemia is at present unknown; it appeared likely, because complement fixation to red cells was found; that some degree of haemolysis would take place. Further investigations are necessary to elucidate this point.

Rifampicin is a new drug with considerable promise as an antituberculosis agent; its reported low toxicity has enhanced its potential use. We are, however, aware of thrombocytopenia occurring in seven patients in another series of 95 on a high-dosage, intermittent rifampicin regimen which also included ethambutol as the companion drug (V. Farga and Sepulveda, personal communication, 1970). In a preliminary survey of 41 of our patients currently receiving rifampicin we have found the red cells of 10 patients to have a weakly positive direct antiglobulin test due to complement on the red cell surface. None of these patients have thrombocytopenia, but three who were not receiving ethambutol as the companion drug appear to have antibodies in low titre, directed against rifampicin, in the serum (Blajchman et al., 1970). The full significance of the results of these tests remains to be elucidated.

We acknowledge the expert technical assistance of Miss E. E. Lloyd and Mr. K. H. Th'ng, also the helpful suggestions of Professor W. R. Pitney, Dr. S. M. Worlledge, and Professor J. V. Dacie. M.A.B. acknowledges the financial support of the Ministry of Health of the Province of Quebec.

The patient here discussed forms one of a group in a trial of rifampicin kindly supplied by Lepetit Pharmaceuticals Ltd.

Requests for reprints should be made to Dr. Peter Stradling, Chest Clinic, Royal Postgraduate Medical School, Du Cane Road, London W.12.

\section{Addendum}

Since submission of this manuscript for publication a second patient has been observed to develop acute thrombocytopenia following rifampicin. Like the first patient, he was on an intermittent high dose regimen (for four months; preceded by three months of daily treatment) but was not receiving ethambutol. The direct antiglobulin test was weakly positive owing to complement on the red cell surface. Anti-rifampicin antibodies were found in the serum before a dose of rifampicin, and were not detectable six hours later when thrombocytopenia was observed.

\section{REFERENCES}

Ackroyd, J. F. (1962), Proceedings of the Royal Society of Medicine, 55 ,

Aster, R. H., Cooper, H. E., and Singer, D. L. (1964), fournal of Laboratory and Clinical Medicine, 63,161.

Blajchman, M. A., Lloyd, E. E. and Worlledge, S. M. (1970). Unpublished observations.

Canetti, G., le Lirzin, M., Porven, G., Rist, N., and Grumbach, F. (1968), Tubercle, 49, 367.

Dacie, J. V., and Lewis, S. M. (1968), Practical Haematology, 4th edn. London, Churchill. Harris, J. W. (1956) fournal of Laboratory and Clinical Medicine, 47,
760 .

Horowitz, H. I., and Nachman, R. L. (1965), Seminars in Haematology,

2, 287.
Miescher, P., and Miescher, A. (1952), Schweizerische medizinische Wochenschrift, 82, 1279.

Pines, A., Raafat, H., and Siddiqui, G. M. (1970), fournal of the Irish Medical Association, 63, 82.

Schulman, N. R. (1964), Annals of Internal Medicine, 60, 506.

Tomasi, T. B., Kunkel, H. G. (1964), Methods in Medical Research, 10, 80 .

Verbist, L., and Gyselen, A. (1968), American Review of Respiratory Disease, 98, 923. 